\title{
Quality of Primary Education in India: An Inter-state Perspective
}

\author{
Anjali Mehra, Urvashi Bali, Nitin Arora \\ School of Social Sciences, Guru Nanak Dev University, Amritsar \\ School of Social Sciences, Guru Nanak Dev University, Amritsar \\ Department of Economics, Panjab University, Chandigarh
}

\section{ABSTRACT}

The present study analyzes the interregional disparities in the quality of primary education in rural India. The study is based on the Annual Status of Education Report, 2010 prepared by Pratham. Quality of Education Index (QEI) has been constructed using three indices: (i) Quality of Teaching Index, (ii) School Infrastructure Index and (iii) Learning Achievement Index. It has been observed that Kerala is the only state which scores the highest in all the three indices whereas states like Bihar, Uttar Pradesh, Assam, Odisha, Jharkhand and majority of North Eastern state are at the bottom. At the regional level a high quality knowledge base on education system reform needs to be developed.

\section{Keywords:}

Education; Interregional disparities; Quality of Education Index; Quality of Teaching Index; School Infrastructure Index; Learning achievement Index.

\section{Academic Discipline and Sub-Disciplines:}

Education; Economics; Public Policy

\section{JEL classification:}

C10, C81, I20, I21, I31

\section{TYPE (METHOD/APPROACH)}

Literary and empirical analysis

\section{Council for Innovative Research}

Peer Review Research Publishing System

\section{Journal of Social Science Research}

\author{
Vol.2, No.1 \\ editor@ijssronline.com \\ www.cirworld.com, www.ijssronline.com
}




\section{INTRODUCTION}

The concept of human development centers around the notion that human welfare depends on various dimensions, with education and health emerging as the prime welfare indicator. According to Schultz (1961) it is not possible to have fruits of modern agriculture and the abundance of modern industry without making large investments in human beings". According to World Bank (2006), Better education and health lead not only to higher individual income due to increased efficiency but is also a necessary precondition for long-term economic growth. Education in general contributes to the growth of an economy through acquisition of training and skills while primary education lays the foundation stone of the capabilities of labor and is a powerful lever for poverty alleviation and socio-economic growth. Its results can be empowering, enabling people to take charge of their lives and make more informed choices, contribute to the building of a democratic polity, increase earning potential and social mobility as well as improve personal and family health and nutrition (particularly for females), and enable women to control their fertility. It is therefore but natural that social returns to primary education are much higher.

The last half century witnessed unprecedented advances in levels of education world over with increase in average school enrollment. But the worldwide improvement in educational indicators is confined to the quantity aspect alone. The learning achievements have been largely compromised. This has resulted in a huge gap between the market definition of required skilled manpower and the existing potential. Hanushek and Wosmann (2007) stressed that the quality of education, measured by the knowledge that student gains is substantially more important for economic growth than the mere quantity of education as measured by number of pupils and number of school years. Quality cannot improve by itself, rather it requires reforms in teacher training; improvements in infrastructural facilities in schools; teachers' motivation; and change in the style of teaching to make it attractive to students.

As India moves towards being a world economic power, the low standards of education reflected by large gender disparity in enrollment, completed education, labor market participation, and lack of infrastructural facilities, has raised legitimate concern about the means through which India will manage to sustain this growth. Ensuring universal primary education by 2015 is a part of Millennium Development Goal, of which India is also a signatory. As the timeline comes nearer, the observed pattern in the education system is a divide between urban and rural educational achievements as well as growing regional inequalities. Literacy rates have been rising sharply from 24.02 percent in 1961 to 74 percent in 2011 but there exists question on other aspects of school education viz access to education, teaching quality, school infrastructure and learning quality. The investment in quality primary education holds the key to inclusive development in burgeoning Indian economy.

Various studies have discussed the reasons for low level of learning achievement. Kumar (2010) and Mooij (2008) emphasized that lack of teacher training and their experience leads to low levels of student achievement, While Aslaam and Kingdon (2011) argued that teachers' classroom practices and the teaching process may matter more to student learning than the teachers' observed resume characteristics. Mehrotra (2006) highlighted lack of teacher accountability as the most important factor undermining the learning teaching process. Unni (2009) and Kaushik (2009) found inadequate infrastructure in schools as the major reason for poor attendance. Naseer, Patnam and Raza (2010) highlighted the role of classroom innovations in primary schools. Barrs (2005) analysed that enhanced local governance has a positive impact on teachers' level of motivation and performance. Bajpai, Dholakia and Sachs (2008) drew attention to problems faced by teachers in schools and recommended efficiency on government's part in disbursing their salaries. Although these studies confirm the fact that lack of infrastructure and quality teachers are the main reason for low learning achievements in schools but none of the studies tried to quantify their impact on the quality of education provided in primary schools of rural India. The present study attempts to do this.

Specifically the objective of the present study is to analyze the interregional disparities in the levels of primary education in rural India in terms of quality of teaching, provision of school infrastructure and learning achievements of students. The 
study is divided into four sections including present one. Section 2 is devoted to database and methodology. Section 3 attempts to analyse the results and is further divided into four sub-sections. Subsection 1 analyses the position of states in terms of Overall Quality of Education Index (QEI) while the subsequent three subsections are devoted to the three components of QEI i.e. it discusses Quality of Teaching Index, analyzes variations in School Infrastructure Index and discusses the Learning Achievement Index, Section 4 concludes the findings and gives policy implications.

\section{Database and Methodology}

The data for present study has been culled out from Annual Status of Education Report (ASER), 2010. The ASER is compiled and published by Pratham India. In ASER report, the data collected from rural primary schools are available for 25 Indian states. Using these data, a Quality of Education Index (QEI) has been constructed for each state. As per our calculations, the QEI is a simple average of 3 indices namely; Quality of Teaching Index (QTI), School Infrastructure Index (SII) and Learning Achievement Index (LAI), i.e.

$$
Q E I=\frac{Q T I+S I I+L A I}{3}
$$

Thus, the QEI will indicate the quality of primary education in Indian states based upon three indicators. It is worth mentioning here that all of these indices have been measured in the scale of 0 to 100 . A value near 100 represent better provision of particular indicator in the given state while, a score nearer to zero depicts dismal performance of the state.

Among these three indicators, the QTI represents the Quality of Teaching which has been constructed using a set of five variables. These variables are proportion of schools following Right To Education norms for i) pupil-teacher ratio; ii) teacher-classroom ratio; iii) number of teachers present during the days of survey; iv) number of schools with head teacher appointed; and v) number of multigrade classes. Each of these variables has been converted into an index using the following formula:

$$
\text { Dimension Index of } X_{i}=\frac{\text { Observed value of } X_{i}-\text { Minimum } X_{i}}{\text { Maximum } X_{i}-\text { Minimum } X_{i}}
$$

Another component of the Quality of Education Index is School Infrastructure Index (SSI), constructed using a set of 12 variables namely; i) Percentage of schools having store/office, ii) percentage of schools having playground, iii) percentage of schools having boundary wall, iv) percentage of schools having drinking water facility, v) percentage of schools with toilet facility; vi) percentage of schools with separate girls toilet; vii) percentage of schools having kitchen shed; viii) percentage of schools having library and books available; ix) percentage of schools with library books in use ; $x$ ) percentage of schools with availability of teacher learning material (TLM) grant in class 2; xi) percentage of schools with availability of teacher learning material (TLM) observed in class 4 and xii) percentage of schools with availability of computers. Each of these variables have been converted into an Index using formula (2) and ranks to each state has been assigned accordingly.

The third component of QEI is Learning Achievement Index (LAI). The availability of any infrastructure is trivial in order to impart the effective and easy learning to students. Four variables have been used to check the learning effectiveness of education system: i) percentage of children who can recognize numbers; ii) percentage of children who can do Subtraction or more; iii) percentage of children who can read letters or more; and iv) percentage of children who can read class 1 Books. Using formula (2) for all these four variables, LAI has been constructed as simple average of these four indices. 


\section{Results and Discussion}

\subsection{Quality of Education Index}

The analysis of Quality of education using QEI has been presented in Table 1. It shows that the state of Kerala tops among the set of 25 states, hence the state of Kerala appears to be the benchmark for other states in terms of quality of primary education. The states of Maharashtra and Himachal Pradesh occupy second and third place. The two other states i.e. Punjab and Sikkim also have attained good quality score and therefore are designated at $4^{\text {th }}$ and $5^{\text {th }}$ rank respectively.

States of Haryana, Gujarat, Nagaland, Tripura, Karnataka, and Uttarakhand rank $7^{\text {th }}, 8^{\text {th }}, 9^{\text {th }}, 10^{\text {th }}, 11^{\text {th }}$ and $12^{\text {th }}$ in Quality of Education Index respectively. These states are above average performers and priority should be given to them while implementing program for uplifting the quality of primary education at aggregate levels. While states of Andhra Pradesh, West Bengal, Arunachal Pradesh, Chhattisgarh, Rajasthan and Meghalaya rank $13^{\text {th }}, 14^{\text {th }}, 15^{\text {th }}, 16^{\text {th }}, 17^{\text {th }}$ and $18^{\text {th }}$ respectively in QEI. All these states are below average performers but are not the laggards. Of these states Andhra Pradesh, Chhattisgarh and West Bengal are suffering from Naxalite movement whereas the others are either tribal states or are dominated by orthodox customs which have hindered the provision of quality education. However, the analysis of laggard states depict that Bihar (25 rank), Uttar Pradesh (24), Assam (23), Orissa (22), Jharkhand (21) and Tamil Nadu (20), appear to be the worst performers of the sample in the quality of education index.

Table 1: Quality of Education Index

\begin{tabular}{|c|c|c|c|c|}
\hline $\begin{array}{c}\text { (I) } \\
\text { States } \\
\end{array}$ & $\begin{array}{c}\text { (II) } \\
\text { Quality of Teaching Index }\end{array}$ & $\begin{array}{c}\text { (III) } \\
\text { School Infrastructure Index }\end{array}$ & $\begin{array}{c}\text { (IV) } \\
\text { Learning Quality Index }\end{array}$ & $\begin{array}{c}(\mathrm{V}) \\
\text { Quality of Education Index }\end{array}$ \\
\hline Andhra Pradesh & $\begin{array}{c}21 \\
(48.66) \\
\end{array}$ & $\begin{array}{c}10 \\
(61.26) \\
\end{array}$ & $\begin{array}{c}12 \\
(59.39) \\
\end{array}$ & $\begin{array}{c}13 \\
(56.44) \\
\end{array}$ \\
\hline Arunachal Pradesh & $\begin{array}{c}6 \\
(74.34) \\
\end{array}$ & $\begin{array}{c}23 \\
(22.33) \\
\end{array}$ & $\begin{array}{c}13 \\
(58.12) \\
\end{array}$ & $\begin{array}{c}15 \\
(51.60) \\
\end{array}$ \\
\hline Assam & $\begin{array}{c}\mathbf{1 4} \\
(61.47)\end{array}$ & $\begin{array}{c}21 \\
(32.79) \\
\end{array}$ & $\begin{array}{c}21 \\
(27.05)\end{array}$ & $\begin{array}{c}23 \\
(40.44)\end{array}$ \\
\hline Bihar & $\begin{array}{c}25 \\
(28.77) \\
\end{array}$ & $\begin{array}{c}19 \\
(40.54) \\
\end{array}$ & $\begin{array}{c}20 \\
(28.28)\end{array}$ & $\begin{array}{c}25 \\
(32.53) \\
\end{array}$ \\
\hline Chhattisgarh & $\begin{array}{c}24 \\
(44.71)\end{array}$ & $\begin{array}{c}15 \\
(52.43)\end{array}$ & $\begin{array}{c}14 \\
(56.07)\end{array}$ & $\begin{array}{c}16 \\
(51.07)\end{array}$ \\
\hline Gujarat & $\begin{array}{c}3 \\
(82.12) \\
\end{array}$ & $\begin{array}{c}3 \\
(80.05) \\
\end{array}$ & $\begin{array}{c}18 \\
(35.81) \\
\end{array}$ & $\begin{array}{c}\mathbf{8} \\
(65.99) \\
\end{array}$ \\
\hline Haryana & $\begin{array}{c}9 \\
(68.00)\end{array}$ & $\begin{array}{c}\mathbf{8} \\
(65.37)\end{array}$ & $\begin{array}{c}11 \\
(66.18)\end{array}$ & $\begin{array}{c}7 \\
(66.52)\end{array}$ \\
\hline Himachal Pradesh & $\begin{array}{c}11 \\
(67.68)\end{array}$ & $\begin{array}{c}7 \\
(66.71)\end{array}$ & $\begin{array}{c}4 \\
(82.71)\end{array}$ & $\begin{array}{c}\mathbf{3} \\
(72.37)\end{array}$ \\
\hline Jharkhand & $\begin{array}{c}16 \\
(60.35)\end{array}$ & $\begin{array}{c}17 \\
(43.55)\end{array}$ & $\begin{array}{c}22 \\
(24.94)\end{array}$ & $\begin{array}{c}21 \\
(42.94)\end{array}$ \\
\hline Karnataka & $\begin{array}{c}12 \\
(67.63)\end{array}$ & $\begin{array}{c}\mathbf{5} \\
(69.07) \\
\end{array}$ & $\begin{array}{c}17 \\
(39.13)\end{array}$ & $\begin{array}{c}11 \\
(58.61)\end{array}$ \\
\hline Kerala & $\begin{array}{c}1 \\
(94.42)\end{array}$ & $\begin{array}{c}1 \\
(91.71)\end{array}$ & $\begin{array}{c}1 \\
(95.54)\end{array}$ & $\begin{array}{c}1 \\
(93.89) \\
\end{array}$ \\
\hline Maharashtra & $\begin{array}{c}4 \\
(76.42)\end{array}$ & $\begin{array}{c}6 \\
(68.15) \\
\end{array}$ & $\begin{array}{c}\mathbf{5} \\
(82.60) \\
\end{array}$ & $\begin{array}{c}\mathbf{2} \\
(75.72)\end{array}$ \\
\hline Manipur & $\begin{array}{c}20 \\
(49.82) \\
\end{array}$ & $\begin{array}{c}24 \\
(18.08) \\
\end{array}$ & $\begin{array}{c}6 \\
(76.24) \\
\end{array}$ & $\begin{array}{c}19 \\
(48.05) \\
\end{array}$ \\
\hline Meghalaya & $\begin{array}{c}8 \\
(71.42)\end{array}$ & $\begin{array}{c}25 \\
(9.04)\end{array}$ & $\begin{array}{c}10 \\
(68.34)\end{array}$ & $\begin{array}{c}18 \\
(49.60)\end{array}$ \\
\hline Mizoram & $\begin{array}{c}\mathbf{5} \\
(76.26)\end{array}$ & $\begin{array}{c}22 \\
(31.90)\end{array}$ & $\begin{array}{c}2 \\
(94.73)\end{array}$ & $\begin{array}{c}6 \\
(67.63)\end{array}$ \\
\hline Nagaland & $\begin{array}{c}2 \\
(85.15) \\
\end{array}$ & $\begin{array}{c}\mathbf{2 0} \\
(37.22)\end{array}$ & $\begin{array}{c}7 \\
(75.52) \\
\end{array}$ & $\begin{array}{c}9 \\
(65.97)\end{array}$ \\
\hline Odisha & $\begin{array}{c}23 \\
(46.76)\end{array}$ & $\begin{array}{c}14 \\
(52.85)\end{array}$ & $\begin{array}{c}19 \\
(28.45)\end{array}$ & $\begin{array}{c}22 \\
(42.68)\end{array}$ \\
\hline Punjab & $\begin{array}{c}\mathbf{1 5} \\
(61.32)\end{array}$ & $\begin{array}{c}\mathbf{2} \\
(81.64)\end{array}$ & $\begin{array}{c}9 \\
(72.02)\end{array}$ & $\begin{array}{c}4 \\
(71.66)\end{array}$ \\
\hline Rajasthan & $\begin{array}{c}10 \\
(67.74)\end{array}$ & $\begin{array}{c}9 \\
(63.16)\end{array}$ & $\begin{array}{c}\mathbf{2 3} \\
(19.13)\end{array}$ & $\begin{array}{c}17 \\
(50.01)\end{array}$ \\
\hline Sikkim & $\begin{array}{c}7 \\
(71.61) \\
\end{array}$ & $\begin{array}{c}12 \\
(58.61) \\
\end{array}$ & $\begin{array}{c}3 \\
(83.19) \\
\end{array}$ & $\begin{array}{c}\mathbf{5} \\
(71.14) \\
\end{array}$ \\
\hline $\begin{array}{l}\text { Tamil } \\
\text { Nadu }\end{array}$ & $\begin{array}{c}18 \\
(57.26)\end{array}$ & $\begin{array}{c}4 \\
(70.95) \\
(7)\end{array}$ & $\begin{array}{c}25 \\
(1.70)\end{array}$ & $\begin{array}{c}20 \\
(43.30)\end{array}$ \\
\hline Tripura & $\begin{array}{c}13 \\
(64.96)\end{array}$ & $\begin{array}{c}18 \\
(42.08)\end{array}$ & $\begin{array}{c}8 \\
(72.09)\end{array}$ & $\begin{array}{c}10 \\
(59.71)\end{array}$ \\
\hline Uttar Pradesh & $\begin{array}{c}22 \\
(47.51)\end{array}$ & $\begin{array}{c}13 \\
(54.54)\end{array}$ & $\begin{array}{c}24 \\
(6.25)\end{array}$ & $\begin{array}{c}24 \\
(36.10)\end{array}$ \\
\hline Uttarakhand & $\begin{array}{c}17 \\
(60.31)\end{array}$ & $\begin{array}{c}11 \\
(60.33)\end{array}$ & $\begin{array}{c}16 \\
(50.36)\end{array}$ & $\begin{array}{c}12 \\
(57.00)\end{array}$ \\
\hline West Bengal & $\begin{array}{c}19 \\
(54.76)\end{array}$ & $\begin{array}{c}16 \\
(46.87)\end{array}$ & $\begin{array}{c}15 \\
(55.92)\end{array}$ & $\begin{array}{c}14 \\
(52.52)\end{array}$ \\
\hline
\end{tabular}

Source: Calculated by Authors, based on ASER 2010

${ }^{*}$ Ranks of respective states given in bold

${ }^{*}$ Figures in parentheses are the index scores 
Development signifies both quantitative and qualitative achievements. For realization of this objective, development priorities, strategies and implementation modalities should be tailored to the special problems, situations and felt needs of the distinct states of India. Quality of teaching, availability of infrastructure and learning achievements all play a very significant role in determining overall quality of education in a state. Lacking at any component may affect adversely the ranking of the given state in terms of Quality of Education at aggregated level. Thus, the analysis of the components of $\mathrm{QEI}$ is required to judge the reasons of the observed performance of given state.

\subsection{Quality of Teaching Index (QTI)}

The QTI as given in Table 2 comprises of pupil-teacher ratio, teacher-classroom ratio, number of teachers present, head teachers appointed and percentage of schools with no multigrade classes. High pupil-teacher ratio in primary schools of India has always been a matter of concern. Under RTE guidelines ideal PTR should be 30:1, but against this in India very few percentages of schools across various states follow the prescribed norm. As a result their PTR index score is very low and they lie at the bottom in terms of this index. These states are Uttarakhand (0), Uttar Pradesh (3.14), Assam (20.60), Odisha (20.35) and Jharkhand (28.6). Uttarakhand being a hilly state, the teachers find it difficult to travel schools located in far off areas. In Uttar Pradesh successive governments have not given priority in appointing teachers whereas in Odisha, the state government has no plan for appointing permanent teachers and therefore people don't find any incentive in joining teaching profession leading to high PTR while the state of Assam is suffering from insurgency as a result of which teachers are not ready to go to remote areas. On the other hand in states like Sikkim (100), Nagaland (93.84) Kerala (93.59), majority of the schools follow the ideal pupil teacher ratio. Under RTE all schools are required to have at least one classroom for every teacher. As per Table 2, column III, Bihar is a laggard state in this regard with zero score followed by Andhra Pradesh (13.19), Mizoram (23.85) and Tripura (29.94). Lack of such facility leads to either multi grade classes or forces students to sit in open verandas.

Table 2: Quality of Teaching Index

\begin{tabular}{|c|c|c|c|c|c|c|}
\hline $\begin{array}{c}(1) \\
\text { States }\end{array}$ & $\begin{array}{c}\text { (II) } \\
\text { Pupil-teacher ratio (Rank) }\end{array}$ & $\begin{array}{c}\text { (III) } \\
\text { Classroom-teacher ratio (Rank) }\end{array}$ & $\begin{array}{c}\text { (IV) } \\
\text { Teachers Present } \\
\text { (Rank) }\end{array}$ & $\begin{array}{c}(\mathrm{V}) \\
\begin{array}{c}\text { Head Teacher Appointed } \\
\text { (Rank) }\end{array}\end{array}$ & $\begin{array}{c}\text { (VI) } \\
\begin{array}{l}\text { School with no Multigrade } \\
\text { classes (Rank) }\end{array}\end{array}$ & $\begin{array}{c}\text { (VII) } \\
\text { Quality of } \\
\text { Teaching Index }\end{array}$ \\
\hline Andhra Pradesh & $\begin{array}{c}13 \\
(57.16)\end{array}$ & $\begin{array}{c}24 \\
(13.19)\end{array}$ & $\begin{array}{c}22 \\
(51.04)\end{array}$ & $\begin{array}{c}12 \\
(92.41) \\
\end{array}$ & $\begin{array}{c}17 \\
(29.48) \\
\end{array}$ & $\begin{array}{c}21 \\
(48.66)\end{array}$ \\
\hline Arunachal Pradesh & $\begin{array}{c}8 \\
(80.02)\end{array}$ & $\begin{array}{c}10 \\
(80.20)\end{array}$ & $\begin{array}{c}19 \\
(64.01)\end{array}$ & $\begin{array}{c}15 \\
(82.75)\end{array}$ & $\begin{array}{c}7 \\
(64.74)\end{array}$ & $\begin{array}{c}6 \\
(74.35)\end{array}$ \\
\hline Assam & $\begin{array}{c}22 \\
(20.60)\end{array}$ & $\begin{array}{c}17 \\
(49.49)\end{array}$ & $\begin{array}{c}8 \\
(83.68)\end{array}$ & $\begin{array}{c}1 \\
(100)\end{array}$ & $\begin{array}{c}10 \\
(53.58)\end{array}$ & $\begin{array}{c}14 \\
(61.47)\end{array}$ \\
\hline Bihar & $\begin{array}{l}11 \\
(62.68)\end{array}$ & $\begin{array}{l}25 \\
25 \\
(0)\end{array}$ & $\begin{array}{c}21 \\
(57.74)\end{array}$ & $\begin{array}{l}25 \\
(0)\end{array}$ & $\begin{array}{c}20 \\
(23.46)\end{array}$ & $\begin{array}{c}25 \\
28.78)\end{array}$ \\
\hline Chhattisgarh & $\begin{array}{c}19 \\
(36.93)\end{array}$ & $\begin{array}{c}19 \\
(40.69)\end{array}$ & $\begin{array}{c}17 \\
(66.10)\end{array}$ & $\begin{array}{c}24 \\
(55.17)\end{array}$ & $\begin{array}{c}19 \\
(24.74)\end{array}$ & $\begin{array}{c}24 \\
(44.71)\end{array}$ \\
\hline Gujarat & $\begin{array}{c}6 \\
(81.03) \\
\end{array}$ & $\begin{array}{c}3 \\
(91.37) \\
\end{array}$ & $\begin{array}{c}1 \\
(100)\end{array}$ & $\begin{array}{c}1 \\
(100)\end{array}$ & $\begin{array}{c}14 \\
(38.20)\end{array}$ & $\begin{array}{c}3 \\
(82.12)\end{array}$ \\
\hline Haryana & $\begin{array}{c}12 \\
(57.53) \\
\end{array}$ & $\begin{array}{c}15 \\
(68.27) \\
\end{array}$ & $\begin{array}{c}10 \\
(66.89) \\
\end{array}$ & $\begin{array}{c}21 \\
(66.89)\end{array}$ & $\begin{array}{c}5 \\
(67.82) \\
\end{array}$ & $\begin{array}{c}9 \\
(68.01) \\
\end{array}$ \\
\hline Himachal Pradesh & $\begin{array}{c}14 \\
(53.39)\end{array}$ & $\begin{array}{c}\frac{13}{13} \\
(72.33)\end{array}$ & $\begin{array}{c}11 \\
(77.82)\end{array}$ & $\begin{array}{c}1 \\
(100)\end{array}$ & $\begin{array}{c}15 \\
(34.87)\end{array}$ & $\begin{array}{l}\frac{11}{11} \\
(67.68)\end{array}$ \\
\hline Jharkhand & $\begin{array}{c}20 \\
(28.64)\end{array}$ & $\begin{array}{c}8 \\
(83.75)\end{array}$ & $\begin{array}{c}11 \\
(77.82)\end{array}$ & $\begin{array}{c}1 \\
(100)\end{array}$ & $\begin{array}{c}22 \\
(11.53)\end{array}$ & $\begin{array}{c}16 \\
(60.35)\end{array}$ \\
\hline Karnataka & $\begin{array}{c}5 \\
(83.41)\end{array}$ & $\begin{array}{c}\mathbf{5} \\
(87.81)\end{array}$ & $\begin{array}{c}6 \\
(92.46)\end{array}$ & $\begin{array}{c}18 \\
(74.48)\end{array}$ & $\begin{array}{l}25 \\
(0)\end{array}$ & $\begin{array}{c}12 \\
(67.64)\end{array}$ \\
\hline Kerala & $\begin{array}{c}3 \\
(93.59)\end{array}$ & $\begin{array}{c}9 \\
(81.47)\end{array}$ & $\begin{array}{c}4 \\
(97.07)\end{array}$ & $\begin{array}{c}1 \\
(100)\end{array}$ & $\begin{array}{c}1 \\
(100)\end{array}$ & $\begin{array}{c}1 \\
(94.43)\end{array}$ \\
\hline Maharashtra & $\begin{array}{l}\frac{100}{10} \\
(67.71)\end{array}$ & $\begin{array}{c}\frac{1}{1} \\
(100)\end{array}$ & $\begin{array}{c}5 \\
(96.23)\end{array}$ & $\begin{array}{c}20 \\
(68.96)\end{array}$ & $\begin{array}{c}11 \\
(49.23)\end{array}$ & $\begin{array}{c}\frac{(74.4)}{4} \\
(76.43)\end{array}$ \\
\hline Manipur & $\begin{array}{c}\mathbf{9} \\
(73.49)\end{array}$ & $\begin{array}{c}\mathbf{2 0} \\
(36.29)\end{array}$ & $\begin{array}{l}25 \\
0)\end{array}$ & $\begin{array}{c}16 \\
(81.37)\end{array}$ & $\begin{array}{c}8 \\
(57.94)\end{array}$ & $\begin{array}{c}20 \\
(49.82)\end{array}$ \\
\hline Meghalaya & $\begin{array}{c}17 \\
(45.10) \\
\end{array}$ & $\begin{array}{c}3 \\
(91.37) \\
\end{array}$ & $\begin{array}{c}3 \\
(98.74) \\
\end{array}$ & $\begin{array}{c}1 \\
(100)\end{array}$ & $\begin{array}{c}\mathbf{2 1} \\
(21.92)\end{array}$ & $\begin{array}{c}8 \\
(71.43) \\
\end{array}$ \\
\hline Mizoram & $\begin{array}{c}4 \\
(89.32) \\
\end{array}$ & $\begin{array}{c}23 \\
(23.85) \\
\end{array}$ & $\begin{array}{c}2 \\
(99.16)\end{array}$ & $\begin{array}{c}1 \\
(100)\end{array}$ & $\begin{array}{c}4 \\
(68.97)\end{array}$ & $\begin{array}{c}5 \\
(76.26)\end{array}$ \\
\hline Nagaland & $\begin{array}{c}\frac{2}{2} \\
(93.84)\end{array}$ & $\begin{array}{c}\frac{11}{11} \\
(77.15)\end{array}$ & $\begin{array}{c}16 \\
(68.61)\end{array}$ & $\begin{array}{c}1 \\
(100)\end{array}$ & $\begin{array}{c}3 \\
(86.15)\end{array}$ & $\begin{array}{c}\frac{2}{2} \\
(85.15)\end{array}$ \\
\hline Odisha & $\begin{array}{c}23 \\
(20.35)\end{array}$ & $\begin{array}{c}16 \\
(65.48)\end{array}$ & $\begin{array}{c}13 \\
(76.56)\end{array}$ & $\begin{array}{c}23 \\
(60)\end{array}$ & $\begin{array}{c}23 \\
(11.41)\end{array}$ & $\begin{array}{c}23 \\
(46.76)\end{array}$ \\
\hline Punjab & $\begin{array}{c}18 \\
(39.57)\end{array}$ & $\begin{array}{c}12 \\
(72.84)\end{array}$ & $\begin{array}{c}13 \\
(76.56)\end{array}$ & $\begin{array}{c}17 \\
(75.86)\end{array}$ & $\begin{array}{c}\mathbf{1 3} \\
(41.79)\end{array}$ & $\begin{array}{c}15 \\
(61.33)\end{array}$ \\
\hline Rajasthan & $\begin{array}{c}15 \\
(52.38)\end{array}$ & $\begin{array}{c}6 \\
(85.78)\end{array}$ & $\begin{array}{c}9 \\
(80.75)\end{array}$ & $\begin{array}{c}11 \\
(93.79)\end{array}$ & $\begin{array}{c}18 \\
(26.02)\end{array}$ & $\begin{array}{c}10 \\
(67.75)\end{array}$ \\
\hline Sikkim & $\begin{array}{c}1 \\
(100) \\
\end{array}$ & $\begin{array}{c}21 \\
(33.24)\end{array}$ & $\begin{array}{c}\mathbf{2 4} \\
(33.05)\end{array}$ & $\begin{array}{c}1 \\
(100)\end{array}$ & $\begin{array}{c}\frac{(20.0)}{2} \\
(91.79)\end{array}$ & $\begin{array}{c}7 \\
(71.62)\end{array}$ \\
\hline Tamil Nadu & $\begin{array}{c}16 \\
(46.85)\end{array}$ & $\begin{array}{c}14 \\
(68.52)\end{array}$ & $\begin{array}{c}18 \\
(65.69)\end{array}$ & $\begin{array}{c}1 \\
(100)\end{array}$ & $\begin{array}{c}24 \\
(5.25)\end{array}$ & $\begin{array}{c}18 \\
(57.27)\end{array}$ \\
\hline Tripura & $\begin{array}{c}\frac{7}{7} \\
(80.90)\end{array}$ & $\begin{array}{c}\frac{22}{22} \\
(29.94)\end{array}$ & $\begin{array}{c}15 \\
(73.22)\end{array}$ & $\begin{array}{c}18 \\
(74.48)\end{array}$ & $\begin{array}{c}6 \\
(66.28)\end{array}$ & $\begin{array}{c}13 \\
13 \\
(64.97)\end{array}$ \\
\hline Uttar Pradesh & $\begin{array}{c}24 \\
(3.14) \\
\end{array}$ & $\begin{array}{c}7 \\
(84.77)\end{array}$ & $\begin{array}{c}23 \\
(42.67)\end{array}$ & $\begin{array}{c}22 \\
(62.75)\end{array}$ & $\begin{array}{c}12 \\
(44.23) \\
\end{array}$ & $\begin{array}{c}22 \\
(47.52)\end{array}$ \\
\hline Uttarakhand & $\begin{array}{l}\frac{10.14)}{25} \\
(0)\end{array}$ & $\begin{array}{c}\frac{2}{2} \\
(99.49)\end{array}$ & $\begin{array}{c}\frac{7}{7} \\
(85.35)\end{array}$ & $\begin{array}{c}\frac{14}{14} \\
(84.13)\end{array}$ & $\begin{array}{c}\frac{1(44.2)}{16} \\
(32.56)\end{array}$ & $\begin{array}{c}\frac{174.02}{17} \\
(60.31)\end{array}$ \\
\hline West Bengal & $\begin{array}{c}21 \\
(21.85)\end{array}$ & $\begin{array}{c}18 \\
(42.13)\end{array}$ & $\begin{array}{c}20 \\
(61.92)\end{array}$ & $\begin{array}{c}12 \\
(92.41)\end{array}$ & $\begin{array}{c}9 \\
(55.51)\end{array}$ & $\begin{array}{c}19 \\
(54.77)\end{array}$ \\
\hline
\end{tabular}

Source: Same as in Table 1. 
Teachers play a very critical role in providing learning experiences to children in schools. To meet the demand of increasing enrollment and to improve the pupil-teacher ratio in schools, teachers are recruited in large numbers. But teacher absenteeism resulting in the non-availability of teachers in the classrooms has emerged as a major obstacle in improving the quality of education. Among the North Eastern states it is observed that Manipur ( $25^{\text {th }}$ rank) and Sikkim $\left(24^{\text {th }}\right.$ rank) were the laggards in case of Teacher Present Index where only 70.8 percent and 78.7 percent teachers were present respectively on the day of the survey conducted by Pratham. While Gujarat (1st), Mizoram (2nd), Meghalaya (3rd), Kerala (4th), and Maharashtra (5th) are the benchmark states in teacher present category.

Another indicator of QTI is the appointment of the head teachers in the school. The states of Assam, Gujarat, Himachal Pradesh, Jharkhand, Kerala, Meghalaya, Mizoram, Nagaland, Sikkim and Tamil Nadu had 100 as their index score. While Bihar scores zero indicating that it is at the bottom of the table in terms of head teacher appointed index as only 85.5 percent of the schools in the state had head teacher appointed in the schools which clearly shows adhocism in its education policy. One more indicator which affects the teaching quality is the presence of multi grade classes in schools. It has been observed that in various schools across the states, students of standard II are found sitting with one or more other classes. It was observed from column VI of the Table 2 that Karnataka, Tamil Nadu, Odisha, Jharkhand, and Bihar were at the bottom ranks of $25^{\text {th }}, 24^{\text {th }}, 23^{\text {rd }}, 22^{\text {nd }}$ and $21^{\text {st }}$ respectively as all had very high percentages of schools with multi grade class system, while in case of Kerala only $8 \%$ of schools had multigrade class system. Poor PTR and presence of multigrade classes in these states are the reasons for their low QTI. Depending on the respective index scores of states in above mentioned indicators Overall Quality of Teaching Index was constructed. It was observed from the Table that in this Index state of Kerala (94.42) tops the index followed by Nagaland (85.15), Gujarat (82.12), Maharashtra (76.42) and Mizoram (76.26). Of these states Gujarat and Nagaland fall under above average performers in the Overall Quality Index and hence these states have the potential to catch up with the benchmark state. While Bihar (28.78), Chhattisgarh (44.71), Odisha (46.76), Uttar Pradesh (47.52), are the laggards.

\subsection{School Infrastructure Index}

Favorable attitude towards school infrastructure facilitates motivation for increase in school attendance and improves academic performance of students. Therefore another important constituent of QEI has to be School Infrastructure Index. It includes indices relating to provision of store/office, playground, boundary wall, drinking water availability, useable toilets available, girl's toilets useable, kitchen shed, library books being used, teacher learning material in standard II and standard IV and computer availability. From Table 3, it is clear that in School Infrastructure too, Kerala tops the chart followed by Punjab $\left(2^{\text {nd }}\right)$, Gujarat $\left(3^{\text {rd }}\right)$, Tamil Nadu $\left(4^{\text {th }}\right)$, and Karnataka $\left(5^{\text {th }}\right)$. The improvement in position of Punjab is due to the fact that government of Punjab under Sarva Shiksha Abhiyan had made great efforts in order to improve the infrastructure position in schools throughout the state. Also, it is the first state in the country to launch EDUSAT programme which will provide the facility of two-way audio-video interaction with 300 institutions governed by the department of school education across the state. The institutions are connected online with the teaching and co-existing classroom ending at the EDUSAT Hub. But despite a good overall rank under SII, many schools in Punjab (31.2 percent) lack toilet facility especially separate toilets for girls. Situation is no different in Gujarat which is ranked $3^{\text {rd }}$ under SII but 31.9 percent schools do not have useable toilets. The states of Meghalaya (25th), Jharkhand (24th), Arunachal Pradesh (23rd), Chhattisgarh (22nd), Assam (21st) and Bihar (20th) lie at the bottom of the table in Toilet Available and Useable Index. On the other hand, Haryana scores 100 in this Index surpassing Kerala (88.12), which otherwise ranks $1^{\text {st }}$ in the Overall Quality of Education Index. It is imperative that all schools must provide toilet facilities. Under Drinking Water Facility Index majority of states have shown improvement .Himachal Pradesh (96.89), Punjab (96.77), Uttar Pradesh (95.65), Tamil Nadu (93.54) and Gujarat (92.05) have a high score in this index. Where Bihar scores 91.31 in providing drinking water facility it scores only 20.95 in providing toilet facility. In a recent Supreme court ${ }^{1}$ hearing the bench of Justices quoted that denial of the basic right to water and toilet facilities "clearly violates the right to free and compulsory education of children guaranteed under Article 21-A" Therefore a lot needs to be done about providing useable toilet facility in all schools across states in India as infrastructural facilities have a positive relationship with the dropout rates. 
Table 3: School Infrastructure Index

\begin{tabular}{|c|c|c|c|c|c|c|c|c|c|c|c|c|c|}
\hline $\begin{array}{c}\text { (I) } \\
\text { States }\end{array}$ & $\begin{array}{c}\text { (II ) } \\
\text { office/st } \\
\text { ore } \\
\text { /office } \\
\text { cum } \\
\text { store } \\
\text { (Rank) }\end{array}$ & $\begin{array}{c}\text { ( III ) } \\
\text { Playgrou } \\
\text { nd } \\
\text { (Rank) }\end{array}$ & $\begin{array}{l}\text { (IV) } \\
\text { bounda } \\
\text { ry wall } \\
\text { (Rank) }\end{array}$ & $\begin{array}{c}(\mathrm{V}) \\
\text { Drinkin } \\
\mathrm{g} \text { water } \\
\text { provisi } \\
\text { on } \\
\text { availab } \\
\text { le } \\
\text { (Rank) }\end{array}$ & $\begin{array}{c}\text { ( VI) } \\
\text { Toilet } \\
\text { availab } \\
\text { le and } \\
\text { useabl } \\
\text { e } \\
\text { (Rank) }\end{array}$ & $\begin{array}{c}\text { ( VII ) } \\
\text { girls } \\
\text { toilets } \\
\text { availabl } \\
\text { e } \\
\text { \&useab } \\
\text { le } \\
\text { (Rank) }\end{array}$ & $\begin{array}{l}\text { ( VIII ) } \\
\text { kitchen } \\
\text { shed } \\
\text { for } \\
\text { cookin } \\
g \\
\text { midda } \\
\text { y meal } \\
\text { (Rank) }\end{array}$ & $\begin{array}{c}\text { (IX) } \\
\text { Library } \\
\text { books } \\
\text { availab } \\
\text { le } \\
\text { (Rank) }\end{array}$ & $\begin{array}{c}(X) \\
\text { library } \\
\text { books } \\
\text { in use } \\
\text { by } \\
\text { childre } \\
n \\
\text { (Rank) }\end{array}$ & $\begin{array}{c}\text { (XI) } \\
\text { TLM } \\
\text { observ } \\
\text { ed } \\
\text { inStd2 } \\
\text { (Rank) }\end{array}$ & $\begin{array}{c}\text { (XII) } \\
\text { TLM } \\
\text { observ } \\
\text { ed } \\
\text { in Std4 } \\
\text { (Rank) }\end{array}$ & $\begin{array}{c}\text { (XIII ) } \\
\text { Comput } \\
\text { ers } \\
\text { (Rank) }\end{array}$ & $\begin{array}{c}\text { (XIV) } \\
\text { School } \\
\text { Infrastruct } \\
\text { ure Index }\end{array}$ \\
\hline $\begin{array}{l}\text { Andhra } \\
\text { Pradesh }\end{array}$ & $\begin{array}{c}21 \\
(52.62)\end{array}$ & $\begin{array}{c}9 \\
(62.10)\end{array}$ & $\begin{array}{c}\mathbf{9} \\
(56.67)\end{array}$ & $\begin{array}{c}18 \\
(74.06)\end{array}$ & $\begin{array}{c}17 \\
(36.50)\end{array}$ & $\begin{array}{c}16 \\
(40.56)\end{array}$ & $\begin{array}{c}\mathbf{2 0} \\
(33.75)\end{array}$ & $\begin{array}{c}\mathbf{3} \\
(95.64)\end{array}$ & $\begin{array}{c}\mathbf{1} \\
(100)\end{array}$ & $\begin{array}{c}\mathbf{8} \\
(85.95)\end{array}$ & $\begin{array}{c}7 \\
(87.10)\end{array}$ & $\begin{array}{c}7 \\
(10.22)\end{array}$ & $\begin{array}{c}\mathbf{1 0} \\
(61.26)\end{array}$ \\
\hline $\begin{array}{l}\text { Arunachal } \\
\text { Pradesh }\end{array}$ & $\begin{array}{c}15 \\
(73.43)\end{array}$ & $\begin{array}{c}17 \\
(40.42)\end{array}$ & $\begin{array}{c}\mathbf{2 0} \\
(19.07)\end{array}$ & $\begin{array}{c}20 \\
(59.67)\end{array}$ & $\begin{array}{c}23 \\
(9.50)\end{array}$ & $\begin{array}{c}\mathbf{2 3} \\
(13.05)\end{array}$ & $\begin{array}{c}\mathbf{2 1} \\
(27.60)\end{array}$ & $\begin{array}{c}22 \\
(7.37)\end{array}$ & $\begin{array}{c}22 \\
(6.06)\end{array}$ & $\begin{array}{l}25 \\
(0)\end{array}$ & $\begin{array}{c}\mathbf{2 2} \\
(10.88)\end{array}$ & $\begin{array}{c}23 \\
(0.92)\end{array}$ & $\begin{array}{c}\mathbf{2 3} \\
(22.33)\end{array}$ \\
\hline Assam & $\begin{array}{c}22 \\
(40.10)\end{array}$ & $\begin{array}{c}15 \\
(44.92)\end{array}$ & $\begin{array}{c}\mathbf{2 1} \\
(11.17)\end{array}$ & $\begin{array}{c}19 \\
(69.23)\end{array}$ & $\begin{array}{c}\mathbf{2 1} \\
(16.19)\end{array}$ & $\begin{array}{c}24 \\
(9.43)\end{array}$ & $\begin{array}{c}16 \\
(61.57)\end{array}$ & $\begin{array}{c}\mathbf{2 1} \\
(16.08)\end{array}$ & $\begin{array}{c}\mathbf{2 1} \\
(11.59)\end{array}$ & $\begin{array}{c}17 \\
(54.14)\end{array}$ & $\begin{array}{c}17 \\
(57.73)\end{array}$ & $\begin{array}{c}\mathbf{2 1} \\
(1.32)\end{array}$ & $\begin{array}{c}\mathbf{2 1} \\
(32.79)\end{array}$ \\
\hline Bihar & $\begin{array}{c}\mathbf{9} \\
(59.22)\end{array}$ & $\begin{array}{c}19 \\
(18.55)\end{array}$ & $\begin{array}{c}11 \\
(49.59)\end{array}$ & $\begin{array}{c}7 \\
(91.31)\end{array}$ & $\begin{array}{c}\mathbf{2 0} \\
(20.95)\end{array}$ & $\begin{array}{c}21 \\
(22.48)\end{array}$ & $\begin{array}{c}22 \\
(26.75)\end{array}$ & $\begin{array}{c}14 \\
(51.95)\end{array}$ & $\begin{array}{c}14 \\
(34.91)\end{array}$ & $\begin{array}{c}18 \\
(53.13)\end{array}$ & $\begin{array}{c}19 \\
(53.43)\end{array}$ & $\begin{array}{c}16 \\
(4.24)\end{array}$ & $\begin{array}{c}19 \\
(40.54)\end{array}$ \\
\hline Chhattisgarh & $\begin{array}{c}14 \\
(76.14)\end{array}$ & $\begin{array}{c}\mathbf{2 1} \\
(12.10)\end{array}$ & $\begin{array}{c}10 \\
(50.95)\end{array}$ & $\begin{array}{c}8 \\
(89.95)\end{array}$ & $\begin{array}{c}22 \\
(11.44)\end{array}$ & $\begin{array}{c}\mathbf{2 0} \\
(25.90)\end{array}$ & $\begin{array}{c}12 \\
(74.73)\end{array}$ & $\begin{array}{c}9 \\
(74.30)\end{array}$ & $\begin{array}{c}10 \\
(45.84)\end{array}$ & $\begin{array}{c}9 \\
(83.07)\end{array}$ & $\begin{array}{c}9 \\
(80.80)\end{array}$ & $\begin{array}{c}17 \\
(3.98)\end{array}$ & $\begin{array}{c}15 \\
(52.43)\end{array}$ \\
\hline Gujarat & $\begin{array}{c}10 \\
(78.84)\end{array}$ & $\begin{array}{c}\mathbf{7} \\
(72.07)\end{array}$ & $\begin{array}{c}1 \\
(100)\end{array}$ & $\begin{array}{c}6 \\
(92.05)\end{array}$ & $\begin{array}{c}\mathbf{5} \\
(87.90)\end{array}$ & $\begin{array}{c}\mathbf{3} \\
(91.16)\end{array}$ & $\begin{array}{c}10 \\
(79.40)\end{array}$ & $\begin{array}{c}\mathbf{5} \\
(86.48)\end{array}$ & $\begin{array}{c}7 \\
(61.66)\end{array}$ & $\begin{array}{c}4 \\
(95.09)\end{array}$ & $\begin{array}{c}\mathbf{2} \\
(97.27)\end{array}$ & $\begin{array}{c}4 \\
(18.72)\end{array}$ & $\begin{array}{c}\mathbf{3} \\
(80.05)\end{array}$ \\
\hline Haryana & $\begin{array}{c}7 \\
(88.49)\end{array}$ & $\begin{array}{c}3 \\
(80.85)\end{array}$ & $\begin{array}{c}3 \\
(97.13)\end{array}$ & $\begin{array}{c}11 \\
(86.22)\end{array}$ & $\begin{array}{c}1 \\
(100)\end{array}$ & $\begin{array}{c}\mathbf{1} \\
(100)\end{array}$ & $\begin{array}{l}25 \\
(0)\end{array}$ & $\begin{array}{c}11 \\
(65.02)\end{array}$ & $\begin{array}{c}12 \\
(39.39)\end{array}$ & $\begin{array}{c}15 \\
(55.49)\end{array}$ & $\begin{array}{c}16 \\
(58.45)\end{array}$ & $\begin{array}{c}\mathbf{5} \\
(13.41)\end{array}$ & $\begin{array}{c}\mathbf{8} \\
(65.37)\end{array}$ \\
\hline $\begin{array}{l}\text { Himachal } \\
\text { Pradesh }\end{array}$ & $\begin{array}{c}16 \\
(70.89)\end{array}$ & $\begin{array}{c}6 \\
(73.24)\end{array}$ & $\begin{array}{c}15 \\
(35.69)\end{array}$ & $\begin{array}{c}2 \\
(96.89)\end{array}$ & $\begin{array}{c}7 \\
(72.17)\end{array}$ & $\begin{array}{c}7 \\
(71.08)\end{array}$ & $\begin{array}{c}15 \\
(65.81)\end{array}$ & $\begin{array}{c}7 \\
(82.56)\end{array}$ & $\begin{array}{c}9 \\
(52.17)\end{array}$ & $\begin{array}{c}7 \\
(88.15)\end{array}$ & $\begin{array}{c}8 \\
(86.96)\end{array}$ & $\begin{array}{c}13 \\
(4.91)\end{array}$ & $\begin{array}{c}\prime \\
(66.71)\end{array}$ \\
\hline Jharkhand & $\begin{array}{c}8 \\
(85.44)\end{array}$ & $\begin{array}{l}25 \\
(0)\end{array}$ & $\begin{array}{c}18 \\
(21.38)\end{array}$ & $\begin{array}{c}12 \\
(85.11)\end{array}$ & $\begin{array}{c}\mathbf{2 4} \\
(7.77)\end{array}$ & $\begin{array}{c}19 \\
(29.71)\end{array}$ & $\begin{array}{c}19 \\
(47.55)\end{array}$ & $\begin{array}{c}13 \\
(61.67)\end{array}$ & $\begin{array}{c}15 \\
(35.17)\end{array}$ & $\begin{array}{c}10 \\
(73.60)\end{array}$ & $\begin{array}{c}12 \\
(70.63)\end{array}$ & $\begin{array}{c}15 \\
(4.51)\end{array}$ & $\begin{array}{c}1 / \\
(43.55)\end{array}$ \\
\hline Karnataka & $\begin{array}{c}18 \\
(64.63)\end{array}$ & $\begin{array}{c}13 \\
(54.10)\end{array}$ & $\begin{array}{c}7 \\
(65.25)\end{array}$ & $\begin{array}{c}10 \\
(87.71)\end{array}$ & $\begin{array}{c}18 \\
(34.77)\end{array}$ & $\begin{array}{c}11 \\
(55.02)\end{array}$ & $\begin{array}{c}8 \\
(88.74)\end{array}$ & $\begin{array}{c}\mathbf{2} \\
(96.08)\end{array}$ & $\begin{array}{c}\mathbf{4} \\
(83.13)\end{array}$ & $\begin{array}{c}\mathbf{2} \\
(97.96)\end{array}$ & $\begin{array}{c}\mathbf{5} \\
(94.26)\end{array}$ & $\begin{array}{c}11 \\
(7.17)\end{array}$ & $\begin{array}{c}\mathbf{5} \\
(69.07)\end{array}$ \\
\hline Kerala & $\begin{array}{c}\mathbf{5} \\
(92.55)\end{array}$ & $\begin{array}{c}\mathbf{5} \\
(74.60)\end{array}$ & $\begin{array}{c}\mathbf{3} \\
(96.73)\end{array}$ & $\begin{array}{c}\mathbf{1} \\
(100)\end{array}$ & $\begin{array}{c}\mathbf{4} \\
(88.12)\end{array}$ & $\begin{array}{c}\mathbf{5} \\
(82.93)\end{array}$ & $\begin{array}{c}1 \\
(100)\end{array}$ & $\begin{array}{c}6 \\
(85.69)\end{array}$ & $\begin{array}{c}\mathbf{5} \\
(79.97)\end{array}$ & $\begin{array}{c}\mathbf{1} \\
(100)\end{array}$ & $\begin{array}{c}\mathbf{1} \\
(100)\end{array}$ & $\begin{array}{c}\mathbf{1} \\
(100)\end{array}$ & $\begin{array}{c}\mathbf{1} \\
(91.71)\end{array}$ \\
\hline Maharashtra & $\begin{array}{c}\mathbf{2 4} \\
(1.01)\end{array}$ & $\begin{array}{c}\mathbf{2} \\
(90.82)\end{array}$ & $\begin{array}{c}\mathbf{8} \\
(63.35)\end{array}$ & $\begin{array}{c}14 \\
(79.28)\end{array}$ & $\begin{array}{c}12 \\
(59.61)\end{array}$ & $\begin{array}{c}\mathbf{6} \\
(72.08)\end{array}$ & $\begin{array}{c}17 \\
(57.96)\end{array}$ & $\begin{array}{c}\mathbf{4} \\
(89.05)\end{array}$ & $\begin{array}{c}\mathbf{2} \\
(85.37)\end{array}$ & $\begin{array}{c}3 \\
(97.80)\end{array}$ & $\begin{array}{c}\mathbf{2} \\
(97.27)\end{array}$ & $\begin{array}{c}3 \\
(24.16)\end{array}$ & $\begin{array}{c}6 \\
(68.15)\end{array}$ \\
\hline Manipur & $\begin{array}{c}20 \\
(58.37)\end{array}$ & $\begin{array}{c}\mathbf{8} \\
(66.01)\end{array}$ & $\begin{array}{l}25 \\
(0)\end{array}$ & $\begin{array}{l}25 \\
(0)\end{array}$ & $\begin{array}{c}19 \\
(31.31)\end{array}$ & $\begin{array}{l}25 \\
(0)\end{array}$ & $\begin{array}{c}\mathbf{2 4} \\
(17.40)\end{array}$ & $\begin{array}{c}\mathbf{2 3} \\
(3.12)\end{array}$ & $\begin{array}{c}23 \\
(5.53)\end{array}$ & $\begin{array}{c}\mathbf{2 1} \\
(15.73)\end{array}$ & $\begin{array}{c}\mathbf{2 0} \\
(16.61)\end{array}$ & $\begin{array}{c}19 \\
(2.92)\end{array}$ & $\begin{array}{c}24 \\
(18.08)\end{array}$ \\
\hline Meghalaya & $\begin{array}{l}25 \\
(0)\end{array}$ & $\begin{array}{c}\mathbf{2 8} \\
(13.67)\end{array}$ & $\begin{array}{c}24 \\
(3.67)\end{array}$ & $\begin{array}{c}\mathbf{2 4} \\
(23.32)\end{array}$ & $\begin{array}{l}25 \\
(0)\end{array}$ & $\begin{array}{c}\mathbf{2 2} \\
(13.25)\end{array}$ & $\begin{array}{c}\mathbf{2 3} \\
(17.83)\end{array}$ & $\begin{array}{c}\mathbf{2 0} \\
(17.43)\end{array}$ & $\begin{array}{c}\mathbf{2 0} \\
(18.31)\end{array}$ & $\begin{array}{c}\mathbf{2 3} \\
(1.01)\end{array}$ & $\begin{array}{l}\mathbf{2 4} \\
(0)\end{array}$ & $\begin{array}{l}24 \\
(0)\end{array}$ & $\begin{array}{c}25 \\
(9.04)\end{array}$ \\
\hline Mizoram & $\begin{array}{c}11 \\
(78.68)\end{array}$ & $\begin{array}{c}\mathbf{2 4} \\
(4.29)\end{array}$ & $\begin{array}{c}16 \\
(33.24)\end{array}$ & $\begin{array}{c}21 \\
(53.84)\end{array}$ & $\begin{array}{c}9 \\
(62.20)\end{array}$ & $\begin{array}{c}13 \\
(43.17)\end{array}$ & $\begin{array}{c}3 \\
(96.60)\end{array}$ & $\begin{array}{l}\mathbf{2 4} \\
(0)\end{array}$ & $\begin{array}{l}24 \\
(0)\end{array}$ & $\begin{array}{c}\mathbf{2 3} \\
(1.01)\end{array}$ & $\begin{array}{l}24 \\
(0)\end{array}$ & $\begin{array}{c}8 \\
(9.82)\end{array}$ & $\begin{array}{c}\mathbf{2 2} \\
(31.90)\end{array}$ \\
\hline Nagaland & $\begin{array}{c}9 \\
(84.60)\end{array}$ & $\begin{array}{c}14 \\
(49.41)\end{array}$ & $\begin{array}{c}13 \\
(43.86)\end{array}$ & $\begin{array}{c}\mathbf{2 3} \\
(39.57)\end{array}$ & $\begin{array}{c}9 \\
(62.20)\end{array}$ & $\begin{array}{c}13 \\
(43.17)\end{array}$ & $\begin{array}{c}\mathbf{3} \\
(96.60)\end{array}$ & $\begin{array}{l}24 \\
(0)\end{array}$ & $\begin{array}{l}24 \\
(0)\end{array}$ & $\begin{array}{c}\mathbf{2 2} \\
(1.35)\end{array}$ & $\begin{array}{c}\mathbf{2 1} \\
(13.18)\end{array}$ & $\begin{array}{c}\mathbf{6} \\
(12.74) \\
\end{array}$ & $\begin{array}{c}\mathbf{2 0} \\
(37.22)\end{array}$ \\
\hline Odisha & $\begin{array}{c}17 \\
(69.37)\end{array}$ & $\begin{array}{c}\mathbf{2 2} \\
(11.71)\end{array}$ & $\begin{array}{c}14 \\
(40.32)\end{array}$ & $\begin{array}{c}13 \\
(80.89)\end{array}$ & $\begin{array}{c}13 \\
(50.75)\end{array}$ & $\begin{array}{c}10 \\
(60.44)\end{array}$ & $\begin{array}{c}18 \\
(49.46)\end{array}$ & $\begin{array}{c}10 \\
(65.81)\end{array}$ & $\begin{array}{c}\mathbf{8} \\
(59.42)\end{array}$ & $\begin{array}{c}12 \\
(70.89)\end{array}$ & $\begin{array}{c}11 \\
(71.77)\end{array}$ & $\begin{array}{c}18 \\
(3.32)\end{array}$ & $\begin{array}{c}14 \\
(52.85)\end{array}$ \\
\hline Punjab & $\begin{array}{c}13 \\
(76.64)\end{array}$ & $\begin{array}{c}10 \\
(59.76)\end{array}$ & $\begin{array}{c}\mathbf{2} \\
(97.68)\end{array}$ & $\begin{array}{c}3 \\
3 \\
(96.77)\end{array}$ & $\begin{array}{c}3 \\
(89.41)\end{array}$ & $\begin{array}{c}\mathbf{2} \\
(96.18)\end{array}$ & $\begin{array}{c}7 \\
(92.56)\end{array}$ & $\begin{array}{c}\mathbf{1} \\
(100)\end{array}$ & $\begin{array}{c}3 \\
(84.71)\end{array}$ & $\begin{array}{c}6 \\
(88.66)\end{array}$ & $\begin{array}{c}6 \\
(89.39)\end{array}$ & $\begin{array}{c}10 \\
(7.96)\end{array}$ & $\begin{array}{c}\mathbf{2} \\
(81.64)\end{array}$ \\
\hline Rajasthan & $\begin{array}{c}\mathbf{2} \\
(97.46)\end{array}$ & $\begin{array}{c}18 \\
(26.17)\end{array}$ & $\begin{array}{c}\mathbf{4} \\
(80.38)\end{array}$ & $\begin{array}{c}16 \\
(78.03)\end{array}$ & $\begin{array}{c}\mathbf{2} \\
(91.36)\end{array}$ & $\begin{array}{c}\mathbf{4} \\
(90.76)\end{array}$ & $\begin{array}{c}14 \\
(69.63)\end{array}$ & $\begin{array}{c}12 \\
(64.02)\end{array}$ & $\begin{array}{c}16 \\
(28.45)\end{array}$ & $\begin{array}{c}13 \\
(62.09)\end{array}$ & $\begin{array}{c}13 \\
(64.89)\end{array}$ & $\begin{array}{c}14 \\
(4.64)\end{array}$ & $\begin{array}{c}9 \\
(63.16)\end{array}$ \\
\hline Sikkim & $\begin{array}{c}\mathbf{1} \\
(100)\end{array}$ & $\begin{array}{c}\mathbf{4} \\
(80.46)\end{array}$ & $\begin{array}{c}25 \\
(4.63)\end{array}$ & $\begin{array}{c}\mathbf{9} \\
(88.95)\end{array}$ & $\begin{array}{c}\mathbf{5} \\
(87.90)\end{array}$ & $\begin{array}{c}\mathbf{8} \\
(66.06)\end{array}$ & $\begin{array}{c}6 \\
(94.90)\end{array}$ & $\begin{array}{c}\mathbf{1 8} \\
(42.12)\end{array}$ & $\begin{array}{c}15 \\
(32.65)\end{array}$ & $\begin{array}{c}19 \\
(42.80)\end{array}$ & $\begin{array}{c}14 \\
(62.89)\end{array}$ & $\begin{array}{l}24 \\
(0)\end{array}$ & $\begin{array}{c}12 \\
(58.61)\end{array}$ \\
\hline Tamil Nadu & $\begin{array}{c}\mathbf{2 3} \\
(36.20)\end{array}$ & $\begin{array}{c}1 \\
(58.98)\end{array}$ & $\begin{array}{c}6 \\
(67.84)\end{array}$ & $\begin{array}{c}\mathbf{5} \\
(93.54)\end{array}$ & $\begin{array}{c}13 \\
(50.75)\end{array}$ & $\begin{array}{c}9 \\
(62.44)\end{array}$ & $\begin{array}{c}\mathbf{2} \\
(97.02)\end{array}$ & $\begin{array}{c}\mathbf{8} \\
(81.22)\end{array}$ & $\begin{array}{c}6 \\
(73.91)\end{array}$ & $\begin{array}{c}\mathbf{5} \\
(94.75)\end{array}$ & $\begin{array}{c}\mathbf{4} \\
(95.27)\end{array}$ & $\begin{array}{c}\mathbf{2} \\
(39.44)\end{array}$ & $\begin{array}{c}\mathbf{4} \\
(70.95)\end{array}$ \\
\hline Tripura & $\begin{array}{c}3 \\
(93.40)\end{array}$ & $\begin{array}{c}1 \\
(100)\end{array}$ & $\begin{array}{c}22 \\
(10.76)\end{array}$ & $\begin{array}{c}22 \\
(43.30)\end{array}$ & $\begin{array}{c}16 \\
(42.98)\end{array}$ & $\begin{array}{c}15 \\
(42.16)\end{array}$ & $\begin{array}{c}10 \\
(79.40)\end{array}$ & $\begin{array}{c}19 \\
(32.40)\end{array}$ & $\begin{array}{c}19 \\
(23.84)\end{array}$ & $\begin{array}{c}\mathbf{2 0} \\
(22.50)\end{array}$ & $\begin{array}{c}\mathbf{2 3} \\
(7.87)\end{array}$ & $\begin{array}{c}12 \\
(6.37)\end{array}$ & $\begin{array}{c}18 \\
(42.08)\end{array}$ \\
\hline Uttar Pradesh & $\begin{array}{c}\mathbf{4} \\
(93.06)\end{array}$ & $\begin{array}{c}16 \\
(43.55)\end{array}$ & $\begin{array}{c}12 \\
(45.36)\end{array}$ & $\begin{array}{c}\mathbf{4} \\
(95.65)\end{array}$ & $\begin{array}{c}15 \\
(47.08)\end{array}$ & $\begin{array}{c}12 \\
(52.81)\end{array}$ & $\begin{array}{c}\mathbf{9} \\
(81.31)\end{array}$ & $\begin{array}{c}16 \\
(47.15)\end{array}$ & $\begin{array}{c}17 \\
(27.93)\end{array}$ & $\begin{array}{c}14 \\
(57.69)\end{array}$ & $\begin{array}{c}15 \\
(61.30)\end{array}$ & $\begin{array}{c}\mathbf{2 0} \\
(1.59)\end{array}$ & $\begin{array}{c}13 \\
(54.54)\end{array}$ \\
\hline Uttarakhand & $\begin{array}{c}6 \\
(91.87)\end{array}$ & $\begin{array}{c}12 \\
(56.44)\end{array}$ & $\begin{array}{c}\mathbf{5} \\
(76.15)\end{array}$ & $\begin{array}{c}15 \\
(78.41)\end{array}$ & $\begin{array}{c}\mathbf{8} \\
(62.63)\end{array}$ & $\begin{array}{c}17 \\
(35.34)\end{array}$ & $\begin{array}{c}\mathbf{5} \\
(96.17)\end{array}$ & $\begin{array}{c}17 \\
(46.14)\end{array}$ & $\begin{array}{c}18 \\
(24.63)\end{array}$ & $\begin{array}{c}11 \\
(72.75)\end{array}$ & $\begin{array}{c}10 \\
(74.92)\end{array}$ & $\begin{array}{c}\mathbf{9} \\
(8.49)\end{array}$ & $\begin{array}{c}11 \\
(60.33)\end{array}$ \\
\hline West Bengal & $\begin{array}{c}12 \\
(77.32)\end{array}$ & $\begin{array}{c}\mathbf{2 3} \\
(6.83)\end{array}$ & $\begin{array}{c}\mathbf{1 7} \\
(31.33)\end{array}$ & $\begin{array}{c}17 \\
(77.04)\end{array}$ & $\begin{array}{c}9 \\
(62.20)\end{array}$ & $\begin{array}{c}18 \\
(34.53)\end{array}$ & $\begin{array}{c}13 \\
(74.39)\end{array}$ & $\begin{array}{c}15 \\
(48.15)\end{array}$ & $\begin{array}{c}11 \\
(39.65)\end{array}$ & $\begin{array}{c}16 \\
(54.65)\end{array}$ & $\begin{array}{c}18 \\
(55.15)\end{array}$ & $\begin{array}{c}\mathbf{2 1} \\
(1.32)\end{array}$ & $\begin{array}{c}16 \\
(46.87)\end{array}$ \\
\hline
\end{tabular}

Source: Same as in Table 1. 
The states of Meghalaya $\left(25^{\text {th }}\right)$, Manipur $\left(24^{\text {th }}\right)$, Arunachal Pradesh $\left(23^{\text {rd }}\right)$, Mizoram $\left(22^{\text {nd }}\right)$, Assam $\left(21^{\text {st }}\right)$ and Nagaland $\left(20^{\text {th }}\right)$ are the worst performers under School Infrastructure Index. Surprisingly all of these are North eastern states. The position of Meghalaya is worst as it scores zero in four indicators: provision of store index, toilet useable index, TLM observed in class IV index and Computer index. Table 3 further reveals that Manipur scores zero in drinking water facility index, separate toilet for girls index and boundary wall index. The states of Mizoram and Nagaland scores zero in the library books available index as well as in Library books in use by children index. Sikkim, another North eastern state ranks $12^{\text {th }}$ under SII, which is a better rank in comparison to other North eastern states. This it can be inferred that except Sikkim the availability of basic school infrastructure in these North Eastern states is not satisfactory. The reason for such a miserable situation of infrastructure in these states can be attributed to the fact that in these states higher education receives the maximum portion of the budget and the primary education receives very low portion of it and also the presence of ULFA and the Maoist movements have not only affected the peace in these states but their operations have also hindered the pace of development here. Therefore more investment for creating basic infrastructure in schools is required.

According to Right to Education Act, every school is required to have a playground, boundary wall and a kitchen shed for cooking mid day meal. Haryana ranks $25^{\text {th }}$ in Kitchen Shed Index followed by Manipur $\left(24^{\text {th }}\right)$, Meghalaya $\left(23^{\text {rd }}\right)$, and Assam $\left(22^{\text {nd }}\right)$. Under Playground Index, ten states out of twenty five score below score of 48.01 with state of Jharkhand being at the bottom. This number increases to twelve states out of twenty five under Boundary Wall Index.

In the globalised age, computer education has become essential and therefore it has become obligatory for children to learn computers but it is possible only when schools have the required computer infrastructure. In 20 states out of 25 covered in the survey less than 10 percent of schools had computers. Kerala is the only state where 75.3 percent of schools had computers followed by Tamil Nadu where 29.7 percent of schools have computers. The gap between the two states is extensive.

\subsection{Learning Achievement Index}

Another factor that affects quality of education is the learning achievements of students. The science of brain development shows that learning needs to be encouraged early and often, both inside and outside of the formal schooling system. According to World Bank (2011), in the primary years, quality teaching is critical for giving students the foundational literacy and numeracy on which lifelong learning depends. Knowledge and skills also contribute to an individual's ability to have a healthy and educated family and engage in civic life. In the present study, the Learning Achievement Index comprises of indices relating to students results falling in the following categories: Percentage that can recognize numbers Index (class I and II), Percentage that can do subtraction or more Index (class III and V), Percentage who can read letters or more Index (class I and II), Percentage that can read class I books Index. On the basis of the results it was found that barring Kerala (1st rank), Mizoram $\left(2^{\text {nd }}\right)$, Sikkim $\left(3^{\text {rd }}\right)$, Himachal Pradesh $\left(4^{\text {th }}\right)$ and Maharashtra $\left(5^{\text {th }}\right)$ all other states showed low learning achievements. In Kerala, Christian missionaries gave boost to education by setting up schools for poor and oppressed. Also, the land reforms introduced in Kerala after 1956 enabled every family to own piece of land and so they could plan for the future and education of their children. Mizoram is another state which has shown remarkable learning achievements. Post 1990 the state government of Mizoram adopted "Each One, Teach One" approach, where illiterates in far-flung areas were identified and volunteers were trained in order to impart education to them. Likewise, the state government of Himachal Pradesh, by giving incentives to teachers has made efforts in reaching the nomads in the hills in order to teach their children (Chugh, 2009). In Maharashtra massive efforts have been made by the government in order to improve the quality of learning in schools. A comprehensive quality improvement program named "People of Maharashtra Initiative" was started right after the implementation of Right to Education Act in this state, where teachers, parents, civil society representatives and like-minded people joined in order to ensure that education that is provided to children maintains a certain degree of quality. 
In the category of laggard states under Learning Achievement Index, the most surprising result is of Tamil Nadu which is the worst performer under this Index. Where it scores 57.26 and 70.95 in Quality of Teaching and School Infrastructure index respectively, its score in learning quality is 1.70 only. When asked about this unexpected score on learning quality from ASER regional officer at Tamil Nadu, it was found that lack of incentives given to teachers is the primary reason for lower learning levels. Majority of schools in Tamil Nadu are government schools and teachers hold permanent posts for quite a long time and therefore show no interest in improving achievement levels of students. Uttar Pradesh (6.25), Rajasthan (19.13), Jharkhand (24.94), Assam (27.05) and Bihar (28.28) follow the league in worst performers under Learning Quality Index. In Rajasthan learning profiles are very flat. Around $65.6 \%$ of schools have multi grade classrooms. A study by Goyal (2007) reveals that teachers in government schools are not trained to teach in a multi-grade classroom context. This disconnection between the realities of the teaching environment and the tools provided to teachers in government schools plausibly impacts negatively on learning outcomes.

Table 4: Learning Achievement Index

\begin{tabular}{|c|c|c|c|c|c|}
\hline $\begin{array}{c}(I) \\
\text { States }\end{array}$ & $\begin{array}{l}\text { (II ) } \\
\text { Percentage of Children Who can } \\
\text { Recognize Numbers (1-2) (Rank) }\end{array}$ & $\begin{array}{c}\text { ( III ) } \\
\text { Who Can Do } \\
\text { Subtraction or More (3- } \\
\text { 5) (Rank) }\end{array}$ & $\begin{array}{c}\text { ( IV ) } \\
\text { Who can Read } \\
\text { Letters or More } \\
(1-2) \text { (Rank) }\end{array}$ & $\begin{array}{c}\text { ( V ) } \\
\text { Who Can Read } \\
\text { Level I Books } \\
\text { (Rank) }\end{array}$ & $\begin{array}{c}\text { ( VI ) } \\
\text { Learning } \\
\text { Achievement } \\
\text { Index }\end{array}$ \\
\hline Andhra Pradesh & $\begin{array}{c}12 \\
(72.64)\end{array}$ & $\begin{array}{c}12 \\
(53.28) \\
\end{array}$ & $\begin{array}{c}15 \\
(64.48)\end{array}$ & $\begin{array}{c}12 \\
(47.13)\end{array}$ & $\begin{array}{c}12 \\
(59.39)\end{array}$ \\
\hline Arunachal Pradesh & $\begin{array}{c}7 \\
(87.46)\end{array}$ & $\begin{array}{c}16 \\
(48.75)\end{array}$ & $\begin{array}{c}\mathbf{8} \\
(82.67) \\
\end{array}$ & $\begin{array}{c}22 \\
(13.62)\end{array}$ & $\begin{array}{c}13 \\
(58.13)\end{array}$ \\
\hline Assam & $\begin{array}{c}19 \\
(40.17)\end{array}$ & $\begin{array}{c}22 \\
(14.28)\end{array}$ & $\begin{array}{c}20 \\
(35.51)\end{array}$ & $\begin{array}{c}20 \\
(18.25)\end{array}$ & $\begin{array}{c}21 \\
(27.06) \\
\end{array}$ \\
\hline Chhattisgarh & $\begin{array}{c}14 \\
(69.51)\end{array}$ & $\begin{array}{c}18 \\
(38.32)\end{array}$ & $\begin{array}{c}13 \\
(69.88)\end{array}$ & $\begin{array}{c}13 \\
(46.59)\end{array}$ & $\begin{array}{c}14 \\
(56.08)\end{array}$ \\
\hline Gujarat & $\begin{array}{c}18 \\
(47.29) \\
\end{array}$ & $\begin{array}{c}\mathbf{2 1} \\
(14.51) \\
\end{array}$ & $\begin{array}{c}17 \\
(52.84) \\
\end{array}$ & $\begin{array}{c}17 \\
(28.61) \\
\end{array}$ & $\begin{array}{c}18 \\
(35.81) \\
\end{array}$ \\
\hline Haryana & $\begin{array}{c}11 \\
(73.50)\end{array}$ & $\begin{array}{c}6 \\
(65.98)\end{array}$ & $\begin{array}{c}11 \\
(71.02)\end{array}$ & $\begin{array}{c}8 \\
(54.22) \\
\end{array}$ & $\begin{array}{c}11 \\
(66.18)\end{array}$ \\
\hline Himachal Pradesh & $\begin{array}{c}9 \\
(84.33)\end{array}$ & $\begin{array}{c}4 \\
(84.58)\end{array}$ & $\begin{array}{c}\mathbf{8} \\
(82.67)\end{array}$ & $\begin{array}{c}4 \\
(79.29)\end{array}$ & $\begin{array}{c}4 \\
(82.72)\end{array}$ \\
\hline Karnataka & $\begin{array}{c}16 \\
(63.24)\end{array}$ & $\begin{array}{c}23 \\
(9.75)\end{array}$ & $\begin{array}{c}16 \\
(64.20)\end{array}$ & $\begin{array}{c}19 \\
(19.34)\end{array}$ & $\begin{array}{c}17 \\
(39.14)\end{array}$ \\
\hline Kerala & $\begin{array}{c}1 \\
(100) \\
\end{array}$ & $\begin{array}{c}2 \\
(88.43) \\
\end{array}$ & $\begin{array}{c}1 \\
(100) \\
\end{array}$ & $\begin{array}{c}2 \\
(93.73) \\
\end{array}$ & $\begin{array}{c}1 \\
(95.54) \\
\end{array}$ \\
\hline Maharashtra & $\begin{array}{c}6 \\
(88.03) \\
\end{array}$ & $\begin{array}{c}\mathbf{8} \\
(62.13) \\
\end{array}$ & $\begin{array}{c}7 \\
(90.34) \\
\end{array}$ & $\begin{array}{c}3 \\
(89.91) \\
\end{array}$ & $\begin{array}{c}5 \\
(82.61) \\
\end{array}$ \\
\hline Manipur & $\begin{array}{c}4 \\
(93.16) \\
\end{array}$ & $\begin{array}{c}7 \\
(65.53) \\
\end{array}$ & $\begin{array}{c}4 \\
(92.04) \\
\end{array}$ & $\begin{array}{c}\mathbf{8} \\
(54.22) \\
\end{array}$ & $\begin{array}{c}6 \\
(76.24) \\
\end{array}$ \\
\hline Meghalaya & $\begin{array}{c}10 \\
(74.07)\end{array}$ & $\begin{array}{c}11 \\
(53.51) \\
\end{array}$ & $\begin{array}{c}10 \\
(80.39) \\
\end{array}$ & $\begin{array}{c}\mathbf{5} \\
(65.39) \\
\end{array}$ & $\begin{array}{c}10 \\
(68.35) \\
\end{array}$ \\
\hline Mizoram & $\begin{array}{c}7 \\
(87.46) \\
\end{array}$ & $\begin{array}{c}1 \\
(100) \\
\end{array}$ & $\begin{array}{c}6 \\
(91.47) \\
\end{array}$ & $\begin{array}{c}1 \\
(100) \\
\end{array}$ & $\begin{array}{c}2 \\
(94.74) \\
\end{array}$ \\
\hline Nagaland & $\begin{array}{c}1 \\
(100) \\
\end{array}$ & $\begin{array}{c}9 \\
(56.91) \\
\end{array}$ & $\begin{array}{c}\mathbf{2} \\
(99.14)\end{array}$ & $\begin{array}{c}14 \\
(46.04) \\
\end{array}$ & $\begin{array}{c}7 \\
(75.53) \\
\end{array}$ \\
\hline Odisha & $\begin{array}{c}\mathbf{2 1} \\
(25.35)\end{array}$ & $(26.98)$ & $\begin{array}{c}19 \\
(37.21)\end{array}$ & $\begin{array}{c}18 \\
(24.25)\end{array}$ & $\begin{array}{c}19 \\
(28.45)\end{array}$ \\
\hline Punjab & $\begin{array}{c}13 \\
(72.36)\end{array}$ & $\begin{array}{c}\mathbf{3} \\
(87.52) \\
\end{array}$ & $\begin{array}{c}12 \\
(70.17) \\
\end{array}$ & $\begin{array}{c}7 \\
(58.03) \\
\end{array}$ & $\begin{array}{c}\mathbf{9} \\
(72.03) \\
\end{array}$ \\
\hline Tamil Nadu & $\begin{array}{l}25 \\
(0)\end{array}$ & $\begin{array}{c}24 \\
(6.80)\end{array}$ & $\begin{array}{l}25 \\
(0)\end{array}$ & $\begin{array}{l}25 \\
(0)\end{array}$ & $\begin{array}{c}\mathbf{2 5} \\
(1.70)\end{array}$ \\
\hline Tripura & $\begin{array}{c}\mathbf{5} \\
(92.02)\end{array}$ & $\begin{array}{c}9 \\
(56.91)\end{array}$ & $\begin{array}{c}\mathbf{5} \\
(91.76)\end{array}$ & $\begin{array}{c}11 \\
(47.68)\end{array}$ & $\begin{array}{c}8 \\
(72.10)\end{array}$ \\
\hline Uttar Pradesh & $\begin{array}{c}\mathbf{2 4} \\
(12.25)\end{array}$ & $\begin{array}{l}15 \\
(0)\end{array}$ & $\begin{array}{c}\mathbf{2 4} \\
(12.21)\end{array}$ & $\begin{array}{c}\mathbf{2 4} \\
(0.54)\end{array}$ & $\begin{array}{c}\mathbf{2 4} \\
(6.25)\end{array}$ \\
\hline Uttarakhand & $\begin{array}{c}17 \\
(49.85)\end{array}$ & $\begin{array}{c}14 \\
(51.47)\end{array}$ & $\begin{array}{c}18 \\
(49.71)\end{array}$ & $\begin{array}{c}10 \\
(50.40)\end{array}$ & $\begin{array}{c}16 \\
(50.36)\end{array}$ \\
\hline West Bengal & $\begin{array}{c}15 \\
(67.2153) \\
\end{array}$ & $\begin{array}{c}17 \\
(45.80) \\
\end{array}$ & $\begin{array}{c}14 \\
(67.04) \\
\end{array}$ & $\begin{array}{c}15 \\
(43.59) \\
\end{array}$ & $\begin{array}{c}15 \\
(55.92) \\
\end{array}$ \\
\hline
\end{tabular}

Source: Same as in Table 1. 
In the state of Bihar majority of students leave school just after completing the primary level of education. Bringing child laborers back to school in Bihar is another challenge. The problems of teacher absenteeism, lack of well educated teachers and incomplete school inspection system are the major problems faced by the states. All the above factors affect the learning achievements negatively. The state of Odhisa faces a different problem. There are sixty two Scheduled Tribes in Odisha. Tribals have their own language, culture, and life style thus no single education policy is effective.

\section{Policy Implications and Conclusion}

Education is a part of concurrent list that means the state as well as centre both have a role to play. In order to achieve the goal of Education for All (EFA), various National Policies on Education (NPE), several projects and programmes have been launched in various states of the country. The first major initiative was the commencing of District Primary Education Programme (DPEP) in 1994-95 followed by Sarva Shiksha Abhiyan (SSA) in 2000-01. The Central government on its part has been launching schemes and allocating funds to the states. But the implementation part lies with the states. Kerala, Punjab and Himachal Pradesh have showed considerable progress in developing school infrastructure under these programmes. But Bihar, Uttar Pradesh and the eight states of North East India have not reaped the benefits of these centrally sponsored schemes. Where the educationally backward states like Bihar and U.P lack the financial capacity to fund the programmes, the states of North East region adopted the SSA only in 2002-03. Thus, In order to deal with their education deficit, allocations should be made corruption free, timely and also require proper governance.

Many families do not send their children to schools because of lack of toilets and drinking water facility. The need of the hour is speedy action in this regard. These facilities are basic rights of children in schools and therefore cannot be compromised.

Under the RTE, 2009 schools are required to have a playground, boundary wall, store room, kitchen shed, library, separate toilets for girls, etc. The Act also lays down the ideal pupil-teacher ratio and teacher -classroom ratios in the schools. These factors determine the teaching quality in schools. A well qualified teacher will impart better learning to students. Also, better incentives to teachers will reduce teacher absenteeism. The three year deadline for full implementation of the Act ends in March 2013. Various states have issued regulations to their respective education departments in order to meet the deadline. But the reality is that no state is near to achieving this target. The states facing Naxalite and Maoist tribulations have problems implementing the Act as peace is disturbed in these states. The states with tribal populations like Odisha, Chhattisgarh, Mizoram, and Meghalaya have to deal with the problem of preparing curriculum and teaching in various tribal languages. Rajasthan faces the issue of gender bias where boys are preferred over girls for education. In such cases the government and NGO's should step in to spread awareness among masses about importance of school education for girls.

The current trend in the education sector is the misuse of the financial allocations made by the government under Sarva Shiksha Abhiyan. The education policy makers need to give more weight to the transparency and accountability factors in government rural schools. The decision makers should also realize that efforts in increasing the enrollment rate or reducing the dropout rates alone will not help in bringing the reforms Indian education sector requires. 


\section{References}

[1] Aslaam, M., \& Kingdon, G. (2011).What can teachers do to raise pupil achievement?. Economics of Education Review, 30 (3), 559-574.

[2] Bajpai, N., Dholakia, R.H., \& Sachs J. D. (2008).Scaling up Primary Education Services in Rural India: Public Investment Requirements and Policy Reform, Center on Globalization and Sustainable Development, Working paper no.34, Columbia University.

[3] Barrs, J. (2005).Factors Contributed by Community Organizations to the Motivation of Teachers in Rural Punjab, Pakistan, and Implications for the Quality of Teaching, International Journal of Educational Development,25(3), 333348.

[4] Chugh, S. (2009).Progress in Literacy and Elementary Education: Study of Himachal Pradesh, Mizoram and Kerala", Social Change, 39(2), 216-238.

[5] Goyal, S. (2007), Achievements in India: A Study of Primary Education in Rajasthan, Wahington,DC: The World Bank.

[6] Hanushek, E. A., \& Wosmann. L. (2007).Education Quality and Economic Growth, Washington, DC.: The World Bank.

[7] Kaushik, A (2009).Private Sector and Quality concerns, Annual Status of Education Report 2007-2009, New Delhi: Pratham.

[8] Kumar, M. S. (2010). Is There a Case for School Vouchers? , Economic and Political Weekly, XLV( 7), 41-45.

[9] Mehrotra, S. (2006). Reforming Elementary Education in India: A Menu of Options, International Journal of Educational Development, 26(3) 261-277.

[10] Mooij, J. (2008). Primary Education, Teachers' Professionalism and Social Class about Motivation and Demotivation of Government School Teachers in India, International Journal of Educational Development, 28(5), 508-523.

[11] Naseer, M. F., Patnam. M., \& Raza. R. (2010). Transforming public schools: Impact of the CRI program on child learning in Pakistan, Economics of Education Review, 29(4),669-683.

[12] Pratham Resource Centre. (2010): Annual Status of Education Report (Rural), Mumbai: Pratham India.

[13] Schultz, T .W. (1961). Investment in Human Capital, The American Review,51(1), 1-17.

[14] Unni, J. (2009).Gender Differentials in Education: Exploring the Capabilities Approach, Economic and Political Weekly, XLIV( 9), 111-117.

[15] World Bank Group Education Strategy 2020. (2011). Learning for All: Investing in People's Knowledge and Skills to Promote Development, Washington, DC: The World Bank.

[16] World Bank Independent Evaluation Group. (2006). From Schooling Access to Learning Outcomes: An Unfinished Agenda, Washington, DC: The World Bank. 